\title{
Pengaruh Kompensasi, Motivasi Karyawan, dan Komitmen Organisasi Terhadap Kinerja Karyawan
}

\author{
Sondang Mariani Rajagukguk \\ Fakultas Ekonomi Program Studi Akuntansi-Univ.Kristen Maranatha \\ (Jl. Prof. Drg. Suria Sumantri No. 65, Bandung) \\ sondangmr2002@yahoo.com \\ Frisca Sylia Intan \\ Fakultas Ekonomi Program Studi Akuntansi-Univ.Kristen Maranatha \\ (Jl. Prof. Drg. Suria Sumantri No. 65, Bandung) \\ frisca.smnjuntak@gmail.com
}

\begin{abstract}
This research examined the effect of compensation, employees motivation and organizational commitment to employees' performance at PT Telkom Indonesia Tbk. Bandung. This study took samples of 56 out of the 146 employees at PT Telkom Indonesia Tbk. Bandung from the Division of Resources Management. Data collected through reviewing literature and field observations such as the distribution of questionnaires. Meanwhile, the sampling technique was done by using purposive sampling method. The test's results of using multiple regression partially ( $t$ test) showed that compensation (X1) had influence on the performance, motivation (X2) did not affect the performance, and organizational commitment (X3) had influence on the performance (Y). While simultaneously ( $F$ test) showed that there was an influence between $X$ and $Y$. Result of the coefficient of determination showed that th $e$ independent variables are compensation, motivation, and organizational commitment simultaneous effect was $37.2 \%$ on performance.
\end{abstract}

Keywords: Compensation, Employees Motivation, Employees Performance, and Organizational Commitment

\section{Pendahuluan}

Dalam era globalisasi saat ini, persaingan semakin hari semakin ketat antara perusahaan-perusahaan untuk mendapatkan pangsa pasarnya. Hal ini mendorong perusahaan untuk mencapai suatu perusahaan yang efektif dan efisien. Keefektifan dan keefisienan tersebut merupakan hal yang sangat diperlukan agar suatu perusahaan memiliki daya saing dan keunggulan bila dibandingkan dengan kompetitornya sehingga perusahaan tersebut dapat bertahan dalam dunia persaingan yang sangat ketat.

Kesuksesan jangka panjang dari sebuah organisasi bergantung pada usaha organisasi tersebut untuk memberikan produk dan jasa yang berkualitas tinggi kepada (Owen, Mundy, Guidl dan Gulid, 2011) stakeholdernya. Akan tetapi kenyataannya, walaupun mempertahankan keunggulan kompetitif bisa dipelajari, masih banyak organisasi yang tidak bisa atau tidak mengerti untuk mempertahankan kinerja yang tinggi dan berkualitas. Ada beberapa faktor yang menyebabkan hal ini terjadi, diantaranya adalah visi dan strategi organisasi yang tidak didukung oleh sistem dan proses organisasional sehingga organisasi memiliki fokus dan pengukuran kinerja yang tidak tepat atau tidak relevan. Kedua, organisasi tidak para senior manajer memiliki pemahaman yang jelas mengenai situasi persaingan di pasar sehingga visi misi dan strategi organisasi menjadi tidak tepat, dan faktor yang terakhir adalah ketidaksesuaian perilaku yang diinginkan untuk menerapkan strategi bisnis dengan permintaan/kebutuhan pasar atau pelangan, hal ini terkait dengan perilaku karyawan atau manajer organisasi tersebut (Kaliprasad, 2006)

Untuk itu, perusahaan perlu memperhatikan pengelolaan yang tepat terhadap sumber daya yang ada agar dapat dimanfaatkan secara optimal. Salah satu sumber daya yang dimiliki perusahaan adalah sumber daya manusia. Hariandja (2002) sumber daya manusia merupakan salah satu faktor yang sangat penting dalam suatu perusahaan disamping faktor yang lain seperti modal. Oleh karena itu SDM harus dikelola dengan baik untuk meningkatkan efektivitas dan efisiensi organisasi.

Menurut Umar (2001) manajemen sumber daya manusia didefinisikan sebagai perencanaan, pengorganisasian, penggerakan dan pengawasan atas pengadaan, pengembangan, kompensasi, 
pengintegrasian, pemeliharaan dan pemutusan hubungan kerja dengan maksud untuk mencapai tujuan organisasi perusahaan secara terpadu. Jadi dapat disimpulkan bahwa potensi sumber daya manusia sangat berpengaruh terhadap upaya suatu organisasi dalam mencapai tujuannya. Oleh karena itu, dengan semakin pesatnya perkembangan ilmu pengetahuan dan teknologi di era globalisasi ini, maka pengelolaan potensi sumber daya manusia yang berkualitas sangat diperlukan untuk meningkatkan keunggulan yang kompetitif bagi perusahaan.

Potensi setiap sumber daya manusia yang ada dalam perusahaan harus dapat dimanfaatkan dengan sebaik-baiknya sehingga mampu memberikan hasil kerja yang maksimal sesuai dengan tujuan perusahaan. Karena manusia merupakan penggerak dan penentu jalannya suatu organisasi. Oleh karena itu hendaknya organisasi memberikan arahan yang positif demi tercapainya tujuan organisasi. Hal ini didukung pendapat Hasibuan (2000) yang menyatakan bahwa manusia selalu berperan aktif dan dominan dalam setiap organisasi. Sebaik-baiknya program yang dibuat oleh perusahaan akan sulit untuk dapat dijalankan tanpa peran aktif karyawan yang dimiliki perusahaan tersebut. Dari pernyataan tersebut dapat diketahui arti penting karyawan dalam suatu perusahaan.

Tujuan perusahaan dapat tercapai jika perusahaan memiliki sumber daya manusia yang baik dan memiliki kinerja yang tinggi. Namun kinerja karyawan didalam suatu organisasi tidak selalu mengalami peningkatan, terkadang kinerja karyawan mengalami penurunan. Terciptanya kinerja pegawai yang tinggi sangatlah tidak mudah dikarenakan kinerja karyawan dapat timbul apabila organisasi mampu menciptakan kondisi yang dapat mendorong dan memungkinkan karyawan untuk mengembangkan dan meningkatkan kemampuan mereka serta keterampilan yang dimiliki secara maksimal sehingga karyawan dapat memberikan kontribusi yang positif bagi perusahaan. Salah satu upaya yang dapat ditempuh perusahaan untuk dapat memengaruhi kinerja karyawan diantaranya adalah pemberian kompensasi karena kepuasan kompensasi dapat mempengaruhi perilaku karyawan untuk bekerja lebih bersemangat dan memacu tingginya kinerja (Handoko, 2008).

Berdasarkan konteks penelitian di atas, berikut diuraikan pertanyaan pokok yang akan dicari jawabannya melalui penelitian ini, yaitu:

1. Bagaimana pengaruh antara kompensasi terhadap kinerja karyawan?

2. Bagaimana pengaruh antara motivasi karyawan terhadap kinerja karyawan?

3. Bagaimana pengaruh antara komitmen organisasi terhadap kinerja karyawan?

4. Bagaimana pengaruh antara kompensasi, motivasi karyawan dan komitmen organisasi terhadap kinerja karyawan?
Tujuan dari penelitian ini adalah untuk menjawab pertanyaan penelitian yang dikemukan di atas. Penelitian ini akan menjawab pertanyaan penelitian tersebut dengan melakukan studi kasus pada PT. Telekomunikasi Indonesia Tbk. Khususnya Divisi Human Capital.

\section{Kerangka Teoritis $\quad \& \quad$ Kerangka Pemikiran dan Hipotesis}

Menurut Sastrohadiwiryo (2005) menyatakan bahwa kompensasi adalah imbalan jasa atau balas jasa yang diberikan oleh organisasi kepada para tenaga kerja, karena tenaga kerja tersebut telah memberikan sumbangan tenaga dan pikiran demi kemajuan organisasi guna mencapai tujuan yang telah ditetapkan. Jika dikelola dengan baik, maka kompensasi membantu organisasi mencapai tujuan dan memperoleh, memelihara, dan menjaga pegawai dengan baik. Sebaliknya tanpa kompensasi yang memadai, maka pegawai yang ada saat ini sangat mungkin akan meninggalkan organisasi, dan organisasi akan kesulitan untuk merekrut kembali pegawai yang sesuai dengan kebutuhan.

Sedangkan menurut Panggabean (2004) kompensasi dapat didefinisikan sebagai setiap bentuk penghargaan yang diberikan kepada karyawan sebagai balas jasa atas kontribusi yang mereka berikan kepada organisasi. Menurut Rivai (2004) kompensasi merupakan sesuatu yang diterima karyawan sebagai pengganti kontribusi jasa mereka pada perusahaan. Kompensasi adalah semua pendapatan yang berbentuk uang, barang langsung maupun tidak langsung yang diterima karyawan sebagai imbalan atas jasa yang diberikan kepada perusahaan (Hasibuan, 2011).

Banyak pendapat yang menyatakan tentang jenis-jenis kompensasi yang diterima oleh karyawan. Salah satunya menurut Rivai (2004) kompensasi terbagi menjadi dua yaitu:1) Kompensasi finansial yang dibedakan menjadi kompensasi langsung dan kompensasi tidak langsung (tunjangan). Kompensasi finansial langsung terdiri atas pembayaran pokok (gaji, upah), pembayaran prestasi, pembayaran insentif, komisi, bonus, bagian keuntungan, opsi saham, sedangkan pembayaran tertangguh meliputi tabungan hari tua, saham kumulatif. Sedangkan kompensasi finansial tidak langsung terdiri atas proteksi yang meliputi asuransi, pesangon, sekolah anak, pensiun. Kompensasi luar jam kerja meliputi lembur, hari besar, cuti sakit, cuti hamil, sedangkan berdasarkan fasilitas meliputi rumah, biaya pindah, dan kendaraan. 2) Kompensasi non-finansial, merupakan imbalan dalam bentuk kepuasan seseorang yang diperoleh dari pekerjaan itu sendiri, atau dari lingkungan baik secara fisik atau psikologis dimana orang tersebut bekerja. Contohnya adalah karir yang meliputi aman pada jabatan, peluang promosi, 
pengakuan karya, temuan baru, prestasi istimewa, sedangkan lingkungan kerja meliputi penerimaan pujian, lingkungan yang bersahabat, nyaman bertugas, menyenangkan dan kondusif.

Menurut Mondy dan Noe, kompensasi finansial langsung terdiri dari a) gaji yang merupakan imbalan finansial yang dibayarkan kepada karyawan secara teratur, seperti tahunan, caturwulan, bulanan atau mingguan; b) upah, merupakan imbalan finansial langsung dibayarkan kepada para pekerja berdasarkan jam kerja, jumlah barang yang dihasilkan atau banyaknya pelayanan yang diberikan. Jadi tidak seperti gaji yang jumlahnya relatif tetap, besarnya upah dapat berubah-ubah; c) insentif, merupakan imbalan langsung yang dibayarkan kepada karyawan karena kinerjanya melebihi standar yang ditentukan.; d) bonus, merupakan pembayaran satu kali yang tidak menjadi bagian dari gaji pokok karyawan (Mathis dan Jackson, 2000).

Dengan mengasumsikan bahwa uang dapat digunakan untuk mendorong karyawan bekerja lebih giat lagi, maka mereka yang produktif lebih menyukai gajinya dibayarkan berdasarkan hasil kerja. Untuk itu diperlukan kemampuan untuk menentukan standar yang tepat. Tidak terlalu mudah untuk dicapai dan juga tidak terlalu sulit. Standar yang terlalu mudah tentunya tidak menguntungkan bagi perusahaan. Sedangkan yang terlalu sulit menyebabkan karyawan frustasi.

Kompensasi finansial tidak langsung (fringe benefit) merupakan kompensasi tambahan yang diberikan berdasarkan kebijaksanaan perusahaan terhadap semua karyawan dalam usaha meningkatkan kesejahteraan karyawan. Contohnya asuransi kesehatan, asuransi jiwa, dan bantuan perumahan.

Program asuransi merupakan jaminan atau pertanggungan kepada karyawan dan keluarga mereka apabila terjadi suatu resiko finansial atas diri mereka sesuai dengan jumlah polis yang disepakati. Jaminan ini diberikan oleh perusahaan yang bekerja sama dengan perusahaan asuransi. Menurut Rivai (2004) jaminan asuransi yang dapat diberikan kepada karyawan antara lain adalah asuransi kesehatan, asuransi jiwa, asuransi karena ketidakmampuan fisik atau mental karyawan, dan jaminan asuransi lainnya. Program pensiun, menurut Rivai (2004) program ini diberikan kepada karyawan yang telah bekerja pada perusahaan untuk masa tertentu, dan merupakan program dalam rangka memberikan jaminan keamanan finansial bagi karyawan yang sudah tidak produktif. Program ini bukanlah sesuatu yang diharuskan oleh pemerintah sehingga hanya perusahaan swasta bertaraf nasional maupun internasional saja yang biasanya menggunakan program ini selain instansi pemerintah yang memang diwajibkan memberikan dana pensiun kepada pegawai tetapnya. Bayaran saat tidak masuk kerja, menurut Rivai (2004) yang termasuk dalam kategori ini adalah istirahat selama jam kerja, cuti sakit, cuti dan liburan, bebas dari kehadiran, serta asuransi pengangguran.

Konsep motivasi sebagai bentuk dorongan dari dalam diri karyawan untuk bertindak atau berperilaku. Motivasi merupakan konsep yang menjelaskan alasan di balik suatu tindakan yang diamati. Motivasi hanya bisa diamati dari kondisi yang ada dan perilaku yang mengikutinya (Gibson, 2012). Definisi lain mengenai motivasi dikemukakan oleh Robbins dan Judge (2013), sebagai bentuk proses yang menjelaskan intensitas, arah, dan ketekunan seorang individu dalam upayanya mencapai sasaran. Ketiga elemen utama dalam definisi tersebut mengandung arti. Intensitas berhubungan dengan seberapa giat seseorang berusaha. Namun, intensitas yang tinggi sepertinya tidak akan menghasilkan prestasi kerja yang memuaskan kecuali upaya tersebut dikaitkan dengan arah yang menguntungkan organisasi. Sedangkan dimensi ketekunan merupakan ukuran mengenai berapa lama seseorang bisa mempertahankan usahanya.

Luthans (2006) memandang motivasi sebagai suatu sistem yang terdiri dari: 1) kebutuhan, yang tercipta setiap kali ada ketidakseimbangan psikologi dan fisiologis. 2) dorongan atau motif (istilah kedua sering digunakan secara bergantian), yang dibentuk untuk mengurangi kebutuhan. 3) Insentif yang didefinisikan sebagai sesuatu yang akan meringankan kebutuhan dan mengurangi adanya dorongan.

Menurut Maslow yang dikutip oleh Hasibuan (2008), bahwa motivasi kerja karyawan dipengaruhi oleh kebutuhan fisik, kebutuhan akan keamanan dan keselamatan, kebutuhan sosial, kebutuhan akan penghargaan diri, dan kebutuhan perwujudan diri. Kemudian dari faktor kebutuhan tersebut, diturunkan menjadi indikator-indikator untuk mengetahui tingkat motivasi kerja pada karyawan, yaitu: Kebutuhan fisik ditunjukkan dengan: pemberian gaji, pemberian bonus, uang makan, uang transport, fasilitas perumahan, dan sebagainya. Kebutuhan rasa aman dan keselamatan, ditunjukkan dengan fasilitas keamanan dan keselamatan kerja yang diantaranya seperti adanya jaminan sosial tenaga kerja, dana pensiun, tunjangan kesehatan, asuransi kecelakaan, dan perlengkapan keselamatan tenaga kerja. Kebutuhan sosial ditunjukkan dengan melakukan interaksi dengan orang lain yang diantaranya untuk diterima dalam kelompok dan kebutuhan untuk mencintai dan dicintai. Kebutuhan akan penghargaan ditunjukkan dengan pengakuan dan penghargaan berdasarkan kemampuannya, yaitu kebutuhan untuk dihormati dan dihargai oleh karyawan lain dan pimpinan terhadap prestasi kerja. Kebutuhan perwujudan diri ditunjukkan dengan: sifat pekerjaan yang menarik dan menantang, dimana karyawan tersebut akan mengerahkan kecakapan, kemampuan, keterampilan, dan potensinya. Dalam pemenuhan 
kebutuhan ini dapat dilakukan oleh perusahaan dengan menyelenggarakan pendidikan dan pelatihan.

Komitmen organisasi dapat memengaruhi apakah seorang pegawai tetap bertahan menjadi anggota organisasi atau meninggalkan organisasi untuk mengejar pekerjaan lain. Pegawai meninggalkan organisasi dapat karena terpaksa atau sukarela. Meninggalkan organisasi secara sukarela terjadi ketika pegawai memutuskan untuk berhenti dari organisasi, sedangkan pegawai yang meninggalkan organisasi karena terpaksa bisa terjadi ketika pegawai dipecat oleh organisasi karena alasan tertentu.

Robbins dan Judge (2007) komitmen sebagai suatu keadaan dimana seorang individu memihak organisasi serta tujuan-tujuan dan keinginannya untuk mempertahankan keanggotaannya dalam organisasi. Menurut Robbins dan Judge (2008) salah satu hasil yang spesifik dari budaya organisasi yang kuat adalah menurunnya tingkat perputaran karyawan. Keharmonisan tujuan yang tercapai antara karyawan dan organisasi melalui budaya akan membangun suatu komitmen organisasional dalam diri karyawan.

Gibson, Ivancevich, dan Donnelly (2010) menyatakan bahwa komitmen organisasional melibatkan tiga sikap, yaitu: identifikasi dengan tujuan organisasi, perasaan keterlibatan dalam tugastugas organisasi, serta perasaan loyalitas terhadap organisasi. Hal tersebut berarti pegawai yang berkomitmen terhadap organisasi memandang nilai dan kepentingan organisasi terintegrasi dengan tujuan pribadinya. Pekerjaan yang menjadi tugasnya dipahami sebagai kepentingan pribadi, dan memiliki keinginan untuk selalu loyal demi kemajuan organisasi.

Meyer dan Allen (dalam Luthans, 2008) menjelaskan terdapat tiga dimensi komitmen organisasi, yaitu: a) affective commitment, b) continuance commitment, c) normative commitment.

Istilah kinerja sering digunakan untuk menyebut tingkat keberhasilan individu maupun kelompok individu. Tolak ukur kinerja dapat dilihat dari tujuan dan target dari suatu organisasi. Bastian (2001) kinerja (performance) adalah gambaran mengenai tingkat pencapaian pelaksanaan suatu kegiatan/program/kebijakan dalam mewujudkan sasaran, tujuan, misi dan visi organisasi yang tertuang dalam perumusan skema strategis suatu organisasi.

Kinerja dapat diartikan sebagai hasil usaha seseorang yang dicapai dengan kemampuan dan perbuatan dalam situasi tertentu. Menurut Simamora (2004), kinerja karyawan adalah tingkat para karyawan mencapai persyaratan pekerjaan. Dari pendapat di atas dapat dijelaskan bahwa yang dimaksud dengan kinerja adalah hasil yang dicapai seseorang menurut ukuran yang berlaku untuk pekerjaan yang bersangkutan. Artinya apabila perilaku seseorang memberikan hasil pekerjaan yang sesuai dengan standar atau kriteria yang dibakukan organisasi, maka kinerjanya tergolong baik, dan jika sebaliknya berarti kinerjanya buruk. Atau dengan kata lain, penetapan standar diperlukan untuk mengetahui apakah kinerja karyawan sesuai dengan sasaran yang diharapkan.

Faktor-faktor yang memengaruhi kinerja pegawai adalah sebagai berikut (Mangkunegara, 2005): 1) Faktor Kemampuan, terdiri dari kemampuan potensi (IQ) dan kemampuan reality (knowledge + skill). Pegawai yang memiliki IQ di atas rata-rata dengan pendidikan yang memadai untuk jabatannya dan terampil dalam mengerjakan tugas sehari-hari, maka akan lebih mudah mencapai kinerja yang diharapkan. Oleh karena itu, setiap pegawai perlu ditempatkan pada pekerjaan yang sesuai dengan keahliannya. 2) Faktor Motivasi, terbentuk dari sikap (attitude) seorang pegawai dalam menghadapi situasi kerja. Motivasi merupakan kondisi yang menggerakkan diri pegawai yang terarah untuk mencapai tujuan organisasi (tujuan kerja).

Mondy, Noe, Premeaux (1999) menyatakan bahwa pengukuran kinerja dapat dilakukan dengan menggunakan dimensi: 1) Kuantitas Pekerjaan (Quantity of Work), berhubungan dengan volume pekerjaan dan produktivitas kerja yang dihasilkan oleh pegawai dalam kurun waktu tertentu. 2) Kualitas Pekerjaan (Quality of Work), berhubungan dengan pertimbangan ketelitian, presisi, kerapian, dan kelengkapan di dalam menangani tugas-tugas yang ada di dalam organisasi. 3) Kemandirian (Dependability), berkenaan dengan pertimbangan derajat kemampuan pegawai untuk bekerja dan mengemban tugas secara mandiri dengan meminimalisir bantuan orang lain. Kemandirian juga menggambarkan kedalaman komitmen yang dimiliki oleh pegawai. 4) Inisiatif (Initiative), berkenaan dengan pertimbangan kemandirian, fleksibilitas berfikir, dan kesediaan untuk menerima tanggungjawab. 5) Adaptabilitas (Adaptability), berkenaan dengan kemampuan untuk beradaptasi, mempertimbangkan kemampuan untuk bereaksi terhadap mengubah kebutuhan dan kondisi-kondisi. 6) Kerja Sama (Cooperation), berkaitan dengan pertimbangan kemampuan untuk bekerjasama, dan dengan orang lain.

\section{Metode Penelitian}

Variabel independen dalam penelitian ini adalah kompensasi, motivasi karyawan, dan komitmen organisasi. Sedangkan variabel dependen dalam penelitian ini adalah kinerja karyawan.

Dalam penelitian ini, populasinya adalah karyawan PT. Telekomunikasi Indonesia (TELKOM) Tbk. Bandung Divisi Human Capital Management sebanyak 146 orang. Sampel dalam penelitian ini merupakan keseluruhan populasi karyawan pada Divisi Human Capital Management, akan tetapi 
peneliti hanya memperoleh feedback returned sebanyak 56 orang. Teknik pengambilan sampel dalam penelitian ini menggunakan purposive sampling (probability sampling).

Metode pengumpulan data dilakukan dengan studi kepustakaan dan pengumpulan data primer melalui penyebaran kuesioner kepada karyawan PT. Telekomunikasi Indonesia Tbk. Bandung Divisi Guman Capital.

Pengujian hipotesis dilakukan dengan melakukan uji statistik $F$ dan uji statistik t. Uji statistik F menunjukkan apakah semua variabel independen yaitu kompensasi, motivasi karyawan, dan komitmen organisasi mempunyai pengaruh secara bersama-sama terhadap variabel dependen yaitu kinerja. Sedangkan uji statistik $t$ menunjukkan seberapa jauh pengaruh satu variabel independen secara individual dalam menerangkan variasi variabel dependen.

\section{Hasil Penelitian dan Pembahasan}

Dari hasil pengujian regresi berganda, uji statistik F menunjukkan nilai Sig. F dalam sebesar 0.000. Nilai tersebut lebih kecil dibandingkan dengan tingkat signifikansi yang digunakan yaitu 0.05. Berdasarkan kriteria uji F, dapat disimpulkan bahwa: H0 ditolak dan H1 diterima, yang artinya bahwa kompensasi, motivasi karyawan, dan komitmen organisasi berpengaruh secara simultan terhadap kinerja.

Sedangkan hasil pengujian regresi berganda, uji statistik $t$ ditemukan bahwa: satu, variabel kompensasi memiliki nilai p-value (Asymp Sig) sebesar 0.008. Nilai ini lebih kecil dibandingkan dengan tingkat signifikansi yang digunakan yaitu 0.05. Berdasarkan kriteria uji t, dapat disimpulkan bahwa H0 ditolak artinya ada pengaruh antara kompensasi terhadap kinerja pada tingkat $\alpha=5 \%$ akan tetapi H1 diterima dengan tingkat $\alpha=10 \%$; dua, variabel motivasi karyawan memiliki nilai $p$-value (Asymp Sig) sebesar 0.808. Nilai ini lebih besar dibandingkan dengan tingkat signifikansi yang digunakan yaitu 0.05. Berdasarkan kriteria uji t, dapat disimpulkan bahwa $\mathrm{HO}$ diterima artinya tidak ada pengaruh antara motivasi terhadap kinerja. Hasil pengujian akan menerima $\mathrm{H} 1$ dan menolak $\mathrm{H} 0$ jika $\alpha=10 \%$; tiga, variabel komitmen organisasi memiliki nilai p-value (Asymp Sig) sebesar 0.000. Nilai ini lebih kecil dibandingkan dengan tingkat signifikansi yang digunakan yaitu 0.05. Berdasarkan kriteria uji t, dapat disimpulkan bahwa H0 ditolak artinya ada pengaruh antara komitmen organisasi terhadap kinerja.

\section{Simpulan dan Saran}

Dari hasil perhitungan dan analisis yang dilakukan pada bab sebelumnya, maka membuktikan bahwa: 1)
Secara parsial, masing-masing kompensasi dan motivasi berpengaruh terhadap kinerja dengan tingkat signifikansi sebesar $10 \%$, dan masih secara parsial, komitmen organisasi berpengaruh terhadap kinerja dengan tingkat signifikansi 5\%; 2) Secara simultan, kompensasi, motivasi, dan komitmen organisasi berpengaruh terhadap kinerja. Total presentasi pengaruh ketiga variabel ini terhadap kinerja adalah sebesar $37,2 \%$; sedangkan sisanya $62,8 \%$ dipengaruhi oleh faktor lain di luar model yang ada dalam penelitian ini.

Bisa disebutkan bahwa kinerja pegawai merupakan topik yang sangat signifikan dalam berbagai jenis industri, tidak terkecuali industri jasa seperti PT. Telekomunikasi Tbk. Bandung dimana penelitian ini dilakukan. Untuk penelitian selanjutnya, studi mengenai faktor-faktor yang mempengaruhi kinerja di sektor industri lain seperti sektor produksi perlu dilakukan juga sebagai perbandingan karena sektor jasa dan sektor manufaktur/produksi masingmasing memiliki keunikan yang berbeda terkait dengan faktor yang mempengaruhi kinerja pegawai. Dengan memiliki perspektif dalam dua jenis industri ini tentu akan menjadi masukan dalam meingkatkan kinerja pegawai bagi kemajuan ekonomi bangsa.

Selain itu, untuk penelitian selanjutnya, perlu dilakukan studi mengenai faktor-faktor yang mempengaruhi kinerja dari berbagai sumber penelitian sebelumnya dan melakukan konfirmasi ulang terhadap pengaruh signifikan masing-masing faktor terhadap kinerja, dan juga perlu memperluas populasi dan sampel penelitian tidak hanya satu perusahaan atau satu divisi saja.

\section{Daftar Pustaka}

Bastian, Indra. (2006). Akuntansi Sektor Publik di Indonesia. Yogyakarta: UGM.

Gibson. (2012). Organizations: Behavior, Structure, Processes. New York: McGraw-Hill.

Gibson, Ivancevich, Donnely. (2010). Terjemahan Djoerban Wahid, Sistem Informasi Manajemen. Jakarta: CV Erlangga.

Handoko. (2008). Manajemen Personalia dan Sumber Daya Manusia. Yogyakarta: Liberty.

Hariandja. (2002). Manajemen Sumber Daya Manusia. Jakarta: PT Grasindo.

Hasibuan, Malayu. (2002). Manajemen Sumber Daya Manusia: Dasar dan Kunci Keberhasilan. Jakarta: CV Haji Masagung.

Hasibuan, Malayu. (2008). Manajemen, Dasar, Pengertian, dan Masalah. Jakarta: CV Haji Masagung.

Hasibuan, Malayu. (2011). Manajemen, Dasar, Pengertian, dan Masalah. Jakarta: CV Haji Masagung. Luthans, Fred. (2006). Perilaku Organisasi. Yogyakarta: Penerbit ANDI. 
Jurnal Akuntansi Maranatha — Vol. 9 No. 2, November 2017 : 131 - 136

Luthans, Fred. (2008). Perilaku Organisasi.

Yogyakarta: Penerbit ANDI.

Mangkunegara, Anwar. (2005). Manajemen Sumber Daya Manusia Perusahaan. Bandung: Rosdakarya.

Mathis \& Jackson, John. (2000). Manajemen Sumber Daya Manusia. Jakarta: Penerbit Salemba Empat.

Mondy, Noe \& Premeaux. (1999). Human Resource

Management. Massachusetts: Allyn and Bacon.

Owen, K., Mundy R., Guild, W. \& Guild, R. (2001) .Creating and Sustaining the High Performance Organization. Managing Service Quality, Vol. 11, No. 1, pp. 10-21.

Panggabean, Mutiara. (2004). Manajemen Sumber Daya Manusia. Cetakan Pertama. Jakarta: Ghalia Indonesia.

Rivai. (2004). Manajemen Sumber Daya Manusia untuk Perusahaan: Dari Teori ke Praktek. Jakarta: Grafindo Persada.

Robbins \& Judge. (2007). Perilaku Organisasi. Jakarta: Salemba Empat.

Robbins \& Judge. (2008). Perilaku Organisasi. Jakarta: Salemba Empat.

Robbins \& Judge. (2013). Perilaku Organisasi. Jakarta: Salemba Empat.

Sastrohadiwiryo, B. Siswanto. (2005). Manajemen Tenaga Kerja Indonesia Pendekatan Administratif dan Operasional. Jakarta : PT. Bumi Aksara.

Simamora, Henry. (2004). Manajemen Sumber Daya Manusia. Yogyakarta: BP STIE YKPN.

Umar. (2001). Metode Riset Perilaku Organisasi.

Jakarta: Gramedia Pustaka Utama. 